\title{
Microstructural Changes in Inconel 625 Alloy Fabricated by Laser-Based Powder Bed Fusion Process and Subjected to High-Temperature Annealing
}

\author{
Kewin Gola, Beata Dubiel, and Izabela Kalemba-Rec
}

(Submitted August 30, 2019; in revised form January 14, 2020; published online February 3, 2020)

\begin{abstract}
The microstructure of the laser powder bed additively manufactured Inconel 625 in post-build stress-relief annealed condition and subsequently annealed at a temperature of $600{ }^{\circ} \mathrm{C}$ for 5,100 and $500 \mathrm{~h}$ was investigated by means of light microscopy as well as scanning and transmission electron microscopy. Stressrelieved Inconel 625 exhibited fine cellular-dendritic microstructure characterized by the high dislocation density. Selected area electron diffraction studies allowed to demonstrate that already after $5 \mathrm{~h}$ of annealing at a temperature of $600{ }^{\circ} \mathrm{C}$, precipitation of the $\gamma^{\prime \prime}$ phase in the form of coherent nanoparticles occurred. With the prolongation of the duration of annealing at a temperature of $600{ }^{\circ} \mathrm{C}$ from 5 to $500 \mathrm{~h}$, the gradual dissolution of intercellular areas and decrease in the dislocation density were accompanied by enhanced precipitation of the $\gamma^{\prime \prime}$ phase nanoparticles.
\end{abstract}

Keywords additive manufacturing, high-temperature annealing, Inconel 625 , laser powder bed fusion, microstructure

\section{Introduction}

Inconel 625 is a nickel-based superalloy exhibiting hightemperature strength, good corrosion resistance in several aggressive environments and good weldability (Ref 1-3). Due to its specific properties, it is widely used in different applications, e.g., in automotive, aeronautics and chemical industries. However, like other nickel-based superalloys, Inconel 625 is difficult to machine. Therefore, additive manufacturing (AM) of Inconel 625 is an attractive process for fabrication of parts with complex geometry (Ref 4). One of the mostly applied AM processes, which is used to make Inconel 625 parts, is laser-based powder bed fusion (L-PBF), in which the layers of powder are successively spread on the platform and selectively fused by a laser beam scanning along the predefined path. The process is repeating until the desired shape is obtained. Due to the rapid melting followed by the rapid cooling during the L-PBF processes, the thin layers of melted powder undergo rapid dendritic solidification and thus, in the post-built condition, Inconel 625 exhibits fine cellulardendritic microstructure (Ref 5). To reduce residual stresses and thus avoid distortions before cutting built parts from the

This article is an invited submission to JMEP selected from presentations at The XXII Physical Metallurgy and Materials Science Conference: Advanced Materials and Technologies (AMT 2019) held June 9-12, 2019, in Bukowina Tatrzańska, Poland, and has been expanded from the original presentation.

Kewin Gola, Beata Dubiel, and Izabela Kalemba-Rec, Faculty of Metals Engineering and Industrial Computer Science, AGH University of Science and Technology, al. Mickiewicza 30, 30-059 Kraków, Poland. Contact e-mail: kgola@agh.edu.pl.

building platform, routinely stress-relief annealing is performed at a temperature of $870{ }^{\circ} \mathrm{C}$ for $1 \mathrm{~h}$ (Ref 5-7). Examination of the microstructure of L-PBF-processed Inconel 625 in as-built and stress-relief annealed condition was the subject of several reports (Ref 5, 7-12). The microstructure after post-build annealing at a temperature of 980 and $1150{ }^{\circ} \mathrm{C}$ was also examined (Ref 13). It was revealed that in the as-built condition, the significant segregation of $\mathrm{Ni}$ and $\mathrm{Cr}$ to dendrite cores as well as enrichment of the interdendritic regions in $\mathrm{Nb}$ and Mo occurs (Ref 8, 9, 12, 13). Along the melt pool boundaries, precipitates of the $\gamma^{\prime \prime}$ phase rich in $\mathrm{Nb}$ were observed (Ref 10). Furthermore, in the stress-relieved condition, the presence of the $\gamma^{\prime \prime}$ phase, $\delta$ phase as well as $\mathrm{MC}, \mathrm{M}_{6} \mathrm{C}$ and $\mathrm{M}_{23} \mathrm{C}_{6}$ carbides was reported (Ref 7, 11, 12). However, to the knowledge of the authors, there is limited information about the microstructure of L-PBF Inconel 625 subjected to the postbuild annealing at a temperature higher than the routinely applied stress annealing. Moreover, there are only a few reports on the evolution of the microstructure during the subsequent exposure at a temperature of $600{ }^{\circ} \mathrm{C}$ (Ref 9), which is the working temperature of Inconel 625 in the chemical industry, waste processing and energy systems applications (Ref 14-16).

Therefore, the aim of the present study is characterization of the microstructural changes that occur at micron-/submicronand nanoscale in the L-PBF Inconel 625 subjected to post-build stress-relief annealing at a temperature of $980{ }^{\circ} \mathrm{C}$ for $1 \mathrm{~h}$, as well as after subsequent annealing at a temperature of $600{ }^{\circ} \mathrm{C}$ for 5,100 and $500 \mathrm{~h}$.

\section{Materials and Methods}

The specimens of Inconel 625 delivered by Bibus Menos Sp. z o.o. (Poland) were fabricated by Direct Metal Laser Sintering ${ }^{\circledR}$ (DMLS), being the commercially available L-PBF process of EOS GmbH (Germany). The chemical composition of the alloy is as follows (wt.\%): $63.9 \mathrm{Ni}-21.5 \mathrm{Cr}-1.3 \mathrm{Fe}-8.1 \mathrm{Mo}-$ $3.9 \mathrm{Nb}-0.5 \mathrm{Si}-0.2 \mathrm{Al}-0.2 \mathrm{Ti}-0.2 \mathrm{Co}-0.1 \mathrm{C}-0.1 \mathrm{Mn}$. The fabricated 
specimens in cuboidal shape $15 \mathrm{~mm} \times 15 \mathrm{~mm} \times 15 \mathrm{~mm}$ in size were subjected to the post-build annealing at a temperature of $980{ }^{\circ} \mathrm{C}$ for $1 \mathrm{~h}$ and slowly cooled in an argon atmosphere. The purpose of this treatment was stress relieving and also partial solution annealing. Subsequently, the specimens were isothermally annealed at a temperature of $600{ }^{\circ} \mathrm{C}$ for 5,100 and $500 \mathrm{~h}$ and cooled in air. The microstructural investigation was performed by means of light microscopy (LM), scanning and transmission electron microscopy (SEM, TEM). The LM and SEM analyses of polished sections were carried out using Axio Imager M1m (ZEISS, Germany) and Nova NanoSEM 450 (FEI, USA) microscopes. Thin foils for TEM were prepared by electropolishing. The TEM investigation was performed using JEM-2010 ARP microscope (Jeol, Japan) equipped with INCA EDS system (Oxford Instruments, UK). Selected area electron diffraction (SAED) patterns were analyzed with the use of JEMS v4.4230 software (Pierre Stadelmann, JEMS-SAS, Switzerland). Dislocation density was estimated by the Ham line-intercept method using TEM bright-field (BF) images acquired in two-beam conditions (Ref 17).

\section{Results and Discussion}

Figure 1(a) shows a composite of LM images corresponding to horizontal $(\mathrm{XY})$ and vertical (XZ and $\mathrm{YZ}$ ) sections of the stress-relief annealed specimen. The built direction is marked by an arrow. In the vertical plane (Fig. 1b), the profiles of melt pools forming a so-called fish scale are visible. Figure 1(d) displays the layers of deposited material observed in the horizontal plane. The angle between the laser paths in the successive layers is equal to $67^{\circ}$, according to the scan strategy applied by EOS in DMLS process. SEM observations revealed the cellular-dendritic microstructure within the layers (Fig. 1c and e), which is typical for L-PBF-processed alloys. The width of cells was in the range of 300-400 nm. EDS microanalysis revealed the preferred segregation of $\mathrm{Nb}$ and $\mathrm{Mo}$ to the cell walls. The average concentration of $\mathrm{Nb}$ and $\mathrm{Mo}$, determined from measurements at 20 points, was equal to $1.2 \% \mathrm{Nb}$ and $4.0 \%$ Mo inside the cells; meanwhile, at the cell walls, it amounted to $5.8 \% \mathrm{Nb}$ and $6.2 \% \mathrm{Mo}$. In both the vertical and horizontal planes, besides the cellular forms, the elongated columnar cells and fine dendrites with very short secondary arms were present (Fig. 1c and e). Such elongated cells and dendrites demonstrated epitaxial growth over melt pool boundaries. This shows that the re-melting of the underlying layers during subsequent laser passes allowed for the restart of the grain growth process in the next layers (Ref 18). In the horizontal plane in the vicinity of melt pool boundaries, also the coarser cellular regions occurred (Fig. 1e). Kruth et al. (Ref 19) postulated that in L-PBF-processed alloys, such regions are not overlapped with alternating layers and thus not re-melted by laser, so in effect are less heat-affected, which leads to a coarse microstructure. Similar findings have been reported in the laserassisted direct energy deposited Inconel 625 (Ref 20). TEM microstructural analysis showed the high dislocation density inside cells and splits of dislocations within the cell walls
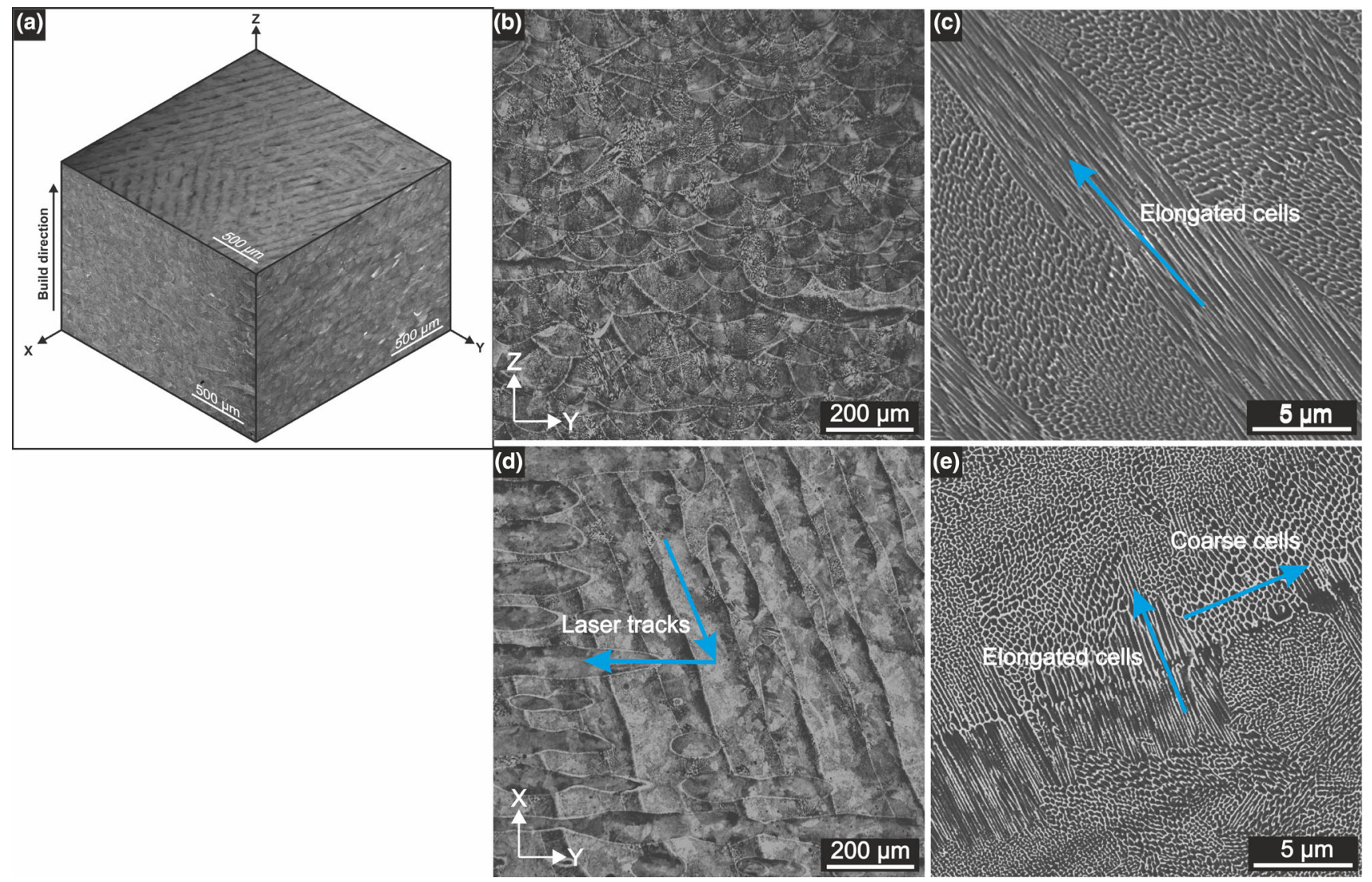

Fig. 1 Microstructure of the L-PBF Inconel 625 after stress-relief annealing at a temperature of $980{ }^{\circ} \mathrm{C}$ for $1 \mathrm{~h}$ : (a) a composite of LM images corresponding to vertical (XZ, YZ) and horizontal (XY) sections of the examined specimen, as well as LM and SEM images of the (b, c) vertical and $(\mathrm{d}, \mathrm{e})$ horizontal sections 

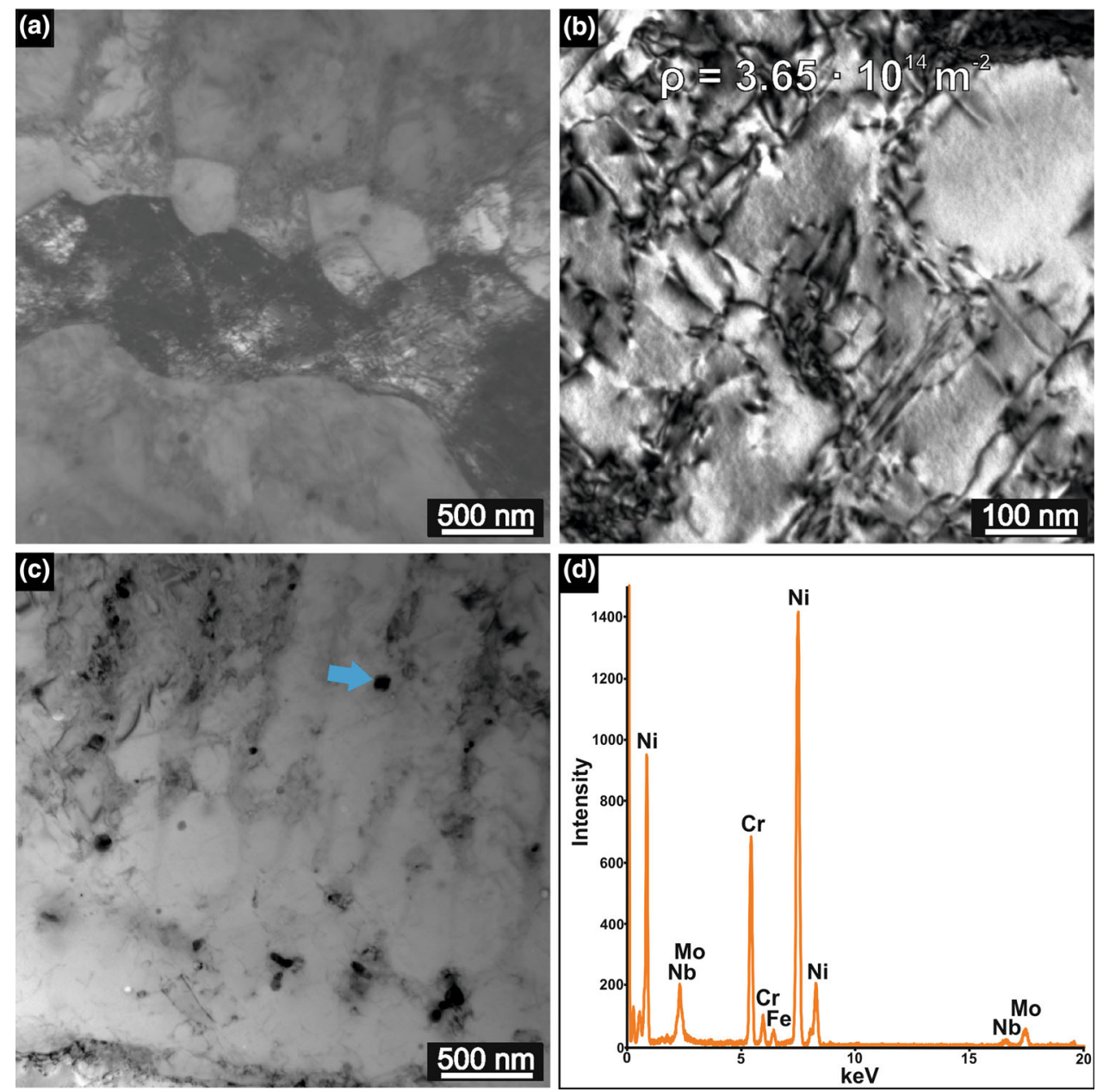

Fig. 2 TEM images of the (a) dislocations arrangements in several neighboring cells and (b) in the enlarged view in the individual cell, (c) precipitates in the L-PBF Inconel 625 after stress-relief annealing at a temperature of $980{ }^{\circ} \mathrm{C}$ for $1 \mathrm{~h}$ and (d) EDS spectrum of the particle with globular morphology marked in (c) by arrow

(Fig. 2a and b). The estimated dislocation density was equal to $3.65 \times 10^{14} \mathrm{~m}^{-2}$. This observation indicates that the annealing at a temperature of $980{ }^{\circ} \mathrm{C}$ for $1 \mathrm{~h}$ is not sufficient to relieve the residual stresses in L-PBF Inconel 625. In the cell walls, precipitates of the secondary phases were observed (Fig. 2c). Such particles were of globular or irregular shapes and up to $100 \mathrm{~nm}$ in size. Figure 2(d) shows the EDS spectrum of the particle with globular morphology marked in Fig. 2(c) by an arrow. Results of quantitative EDS microanalysis of the matrix and exemplary precipitates are given in Table 1 . The concentration of $\mathrm{Si}, \mathrm{Cr}$ and $\mathrm{Fe}$ in individual particles varied in a similar range as in the matrix. The Ni content in the matrix was about $66.6 \%$, while in the precipitates was in the range from 59.0 to $70.4 \%$. In the case of $\mathrm{Nb}$ and $\mathrm{Mo}$, in some particles, the concentration of these elements was at a similar level as in the matrix (e.g., precipitates no 1-3 in Table 1), while in most of the analyzed particles, a significant enrichment in $\mathrm{Nb}$ and $\mathrm{Mo}$ was observed.

The trials of phase identification using SAED patterns revealed that the examined particles may be the precipitates of the $\gamma^{\prime \prime}$ phase (tetragonal, I4/mmm), $\delta$ phase (orthorhombic, Pmmm), P phase (orthorhombic, Pnma), Laves phase (hexagonal, $\mathrm{P} 63 \mathrm{mmc}$ ) or the $\mathrm{M}_{6} \mathrm{C}$ carbides (cubic, Fd3m). However, the solutions of the diffraction patterns provided several possible phases; thus, the undoubted phase identification was not possible. In many previous studies, it was demonstrated that Inconel 625 exhibits a complex precipitation behavior, which varies depending on the production method, e.g., wrought, powder metallurgy, welding, laser cladding or cold metal transfer cladding (Ref 1, 2, 20-30). It has been shown that at a temperature range of $550-900{ }^{\circ} \mathrm{C}$, precipitates of the $\gamma^{\prime}, \gamma^{\prime \prime}, \delta$ and $\mathrm{Ni}_{2}(\mathrm{Cr}, \mathrm{Mo})$ Laves phases, as well as $\mathrm{MC}, \mathrm{M}_{6} \mathrm{C}$ and $\mathrm{M}_{23} \mathrm{C}_{6}$ carbides, can be present in Inconel 625 fabricated using different methods. The further studies are needed to determine which exact phases are present in stress-relief annealed L-PBF Inconel 625.

Figure 3(a), (b), (c) and (d) shows the typical microstructure of the L-PBF Inconel 625 specimen annealed at a temperature of $600{ }^{\circ} \mathrm{C}$ for $5 \mathrm{~h}$ observed on LM, SEM and TEM images. The LM and SEM images did not reveal the pronounced changes in the microstructure, as compared with the stress-relief annealed condition. However, the dislocation density decreased to $2.77 \times 10^{14} \mathrm{~m}^{-2}$ (Fig. 3c). Besides the precipitates of globular and irregular shapes located in the cell walls, the elongated nanoparticles with oscillating contrast in TEM bright-field images were observed. Examples of such precipitates are marked by arrows in Fig. 3(d). SAED patterns allowed to identify them as the precipitates of the $\gamma^{\prime \prime}$ phase. Figure 3(e) 
Table 1 Chemical composition of the matrix and precipitates in the stress-relieved Inconel 625

\begin{tabular}{|c|c|c|c|c|c|c|c|c|c|c|c|c|c|}
\hline \multirow[b]{3}{*}{ Element } & \multicolumn{13}{|c|}{ Elements concentration, at. $\%$} \\
\hline & \multicolumn{3}{|c|}{ Matrix } & \multicolumn{10}{|c|}{ Precipitates } \\
\hline & 1 & 2 & 3 & 1 & 2 & 3 & 4 & 5 & 6 & 7 & 8 & 9 & 10 \\
\hline $\mathrm{Si}$ & 3.3 & 4.3 & 6.2 & 3.0 & 3.7 & 0.4 & 2.6 & 3.0 & 3.6 & 4.5 & 5.5 & 4.7 & 3.4 \\
\hline $\mathrm{Cr}$ & 22.6 & 21.7 & 20.9 & 21.4 & 22.0 & 23.0 & 22.5 & 22.9 & 20.8 & 21.9 & 21.5 & 21.6 & 20.0 \\
\hline $\mathrm{Fe}$ & 1.9 & 2.0 & 1.3 & 1.9 & 1.9 & 1.7 & 1.7 & 1.8 & 1.9 & 1.7 & 1.2 & 1.2 & 1.0 \\
\hline $\mathrm{Ni}$ & 66.4 & 66.6 & 66.7 & 65.5 & 65.3 & 70.4 & 63.1 & 64.8 & 61.2 & 63.0 & 59.0 & 53.1 & 61.4 \\
\hline $\mathrm{Nb}$ & 1.7 & 1.3 & 1.2 & 1.5 & 1.7 & 1.1 & 4.4 & 2.6 & 3.4 & 3.8 & 5.0 & 9.1 & 7.2 \\
\hline Mo & 4.1 & 4.1 & 3.7 & 3.9 & 4.3 & 3.5 & 5.7 & 5.1 & 4.6 & 5.2 & 7.8 & 10.4 & 7.0 \\
\hline
\end{tabular}
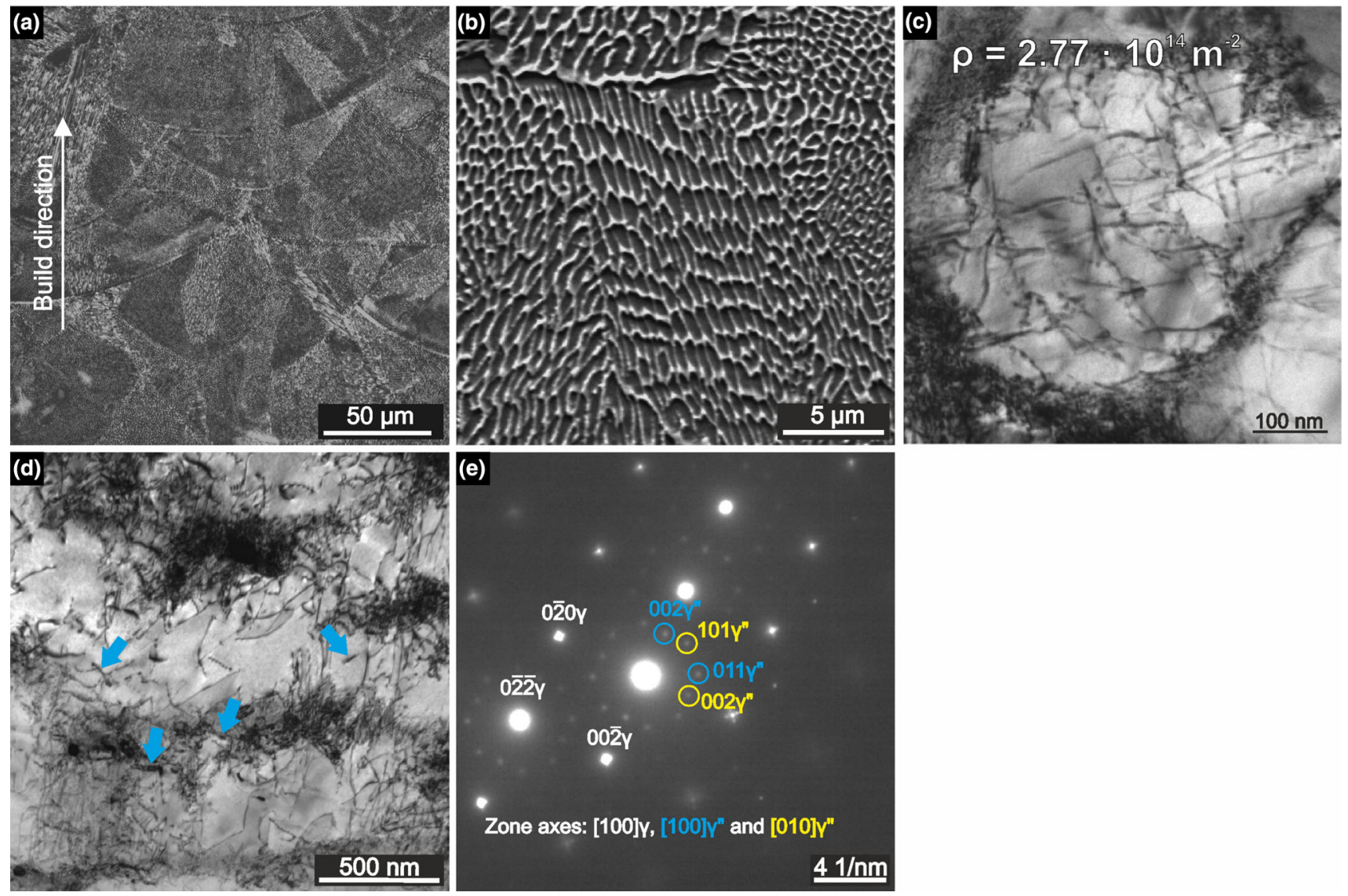

Fig. 3 Microstructure of the L-PBF Inconel 625 after stress-relief annealing at a temperature of $980{ }^{\circ} \mathrm{C}$ for $1 \mathrm{~h}$, followed by annealing at a temperature of $600{ }^{\circ} \mathrm{C}$ for $5 \mathrm{~h}$ : (a) LM image, (b) SEM image, as well as TEM images of (c) dislocations arrangements, (d) precipitates of the $\gamma^{\prime \prime}$ phase (arrowed), (e) [100] zone axis SAED pattern with the $\gamma^{\prime \prime}$ phase diffraction spots of the [100] $\gamma^{\prime \prime}$ and [010] $\gamma^{\prime \prime}$ zone axes

shows the electron diffraction pattern of the matrix $\gamma$ phase [100] zone axis with the lower intensity spots of the $\gamma^{\prime \prime}$ phase [100] and [010] zone axes, which confirms that the precipitates lie on the $\{100\}$ planes of the $\gamma$ matrix. Body centered tetragonal $\mathrm{Ni}_{3} \mathrm{Nb}$-based $\gamma^{\prime \prime}$ phase exhibits ordered structure and precipitates from the $\gamma$ solid solution in the form of coherent precipitates (Ref 31). Precipitates of the $\gamma^{\prime \prime}$ phase were observed in the thin foils prepared from the sections parallel to the horizontal $(\mathrm{XY})$ and vertical (XZ and $\mathrm{YZ}$ ) sections of the examined specimen. The evidence of the $\gamma^{\prime \prime}$ phase was reported also in L-PBF Inconel 625 subjected to stress-relief annealing at a temperature of $870{ }^{\circ} \mathrm{C}$ for $1 \mathrm{~h}$ (Ref 7). Our studies did not confirm those findings for the specimen stress relieved at the higher temperature of $980{ }^{\circ} \mathrm{C}$, whereas it was demonstrated that precipitation of the $\gamma^{\prime \prime}$ phase occurs after subsequent annealing at a temperature of $600{ }^{\circ} \mathrm{C}$ for $5 \mathrm{~h}$ in the whole volume of the L-PBF Inconel 625. Precipitation of the $\gamma^{\prime \prime}$ phase was also observed in wrought Inconel 625 long-time service exposed and subsequently annealed at the temperature of $650{ }^{\circ} \mathrm{C}$ for $1 \mathrm{~h}$ (Ref 2) as well as in TIG and GTA welds heat treated at $700{ }^{\circ} \mathrm{C}$ for $8 \mathrm{~h}$ (Ref 24$)$ and $750{ }^{\circ} \mathrm{C}$ for $4 \mathrm{~h}$ (Ref 25$)$, respectively. Although welding and L-PBF processes seem similar, the 
cooling rates in additive manufacturing are much higher, which results in a very fine and highly segregated microstructure. Our observations indicate that such refinement in L-PBF Inconel 625 contributes to precipitation of the $\gamma^{\prime \prime}$ phase at lower temperature and after a shorter time than in heat-treated welds. Prolongation of the annealing time up to $100 \mathrm{~h}$ resulted in the destabilization of the cellular microstructure manifested by breaks in the continuity of the cell walls, as observed in LM images (Fig. 4a) and more clearly in SEM images (Fig. 4b). Due to the intensification of recovery processes, dislocation density inside the cells further decreased and was equal to $2.55 \times 10^{14} \mathrm{~m}^{-2}$ (Fig. 4c). Moreover, the $\gamma^{\prime \prime}$ phase particles grew and precipitated in all three sets of the $\{100\}$ planes of the $\gamma$ phase matrix, what was demonstrated by the presence of the three sets of diffraction spots form the [100], [010] and [001] zone axes of the $\gamma^{\prime \prime}$ phase (Fig. 4d and e). Streaking of the $\gamma^{\prime \prime}$ diffraction spots in the principal cubic directions is related to the plate-like shape of the particles precipitated on the $\{100\} \gamma$ phase planes. EDS spectra acquired in the locations of the $\gamma^{\prime \prime}$ phase precipitates revealed the presence of the strong $\mathrm{Ni}, \mathrm{Cr}$, Mo and $\mathrm{Nb}$ peaks (Fig. 4f). The $\gamma^{\prime \prime}$ phase nanoparticles were below $100 \mathrm{~nm}$ in size, while the foil thickness was about
$210 \mathrm{~nm}$; thus, this result represents the sum of the $\gamma$ and $\gamma^{\prime \prime}$ phase compositions. It should be pointed out that prolongation of the annealing at a temperature of $600{ }^{\circ} \mathrm{C}$ to $100 \mathrm{~h}$ did not result in intensive precipitation of the $\delta$ phase, as it was shown in other studies even already after stress relieving at a temperature of $870{ }^{\circ} \mathrm{C}$ for $1 \mathrm{~h}$ (Ref 12$)$.

After annealing for $500 \mathrm{~h}$ at a temperature of $600{ }^{\circ} \mathrm{C}$, the progress in homogenizing of the cellular microstructure was insignificant, as compared with the observations of the sample annealed for $100 \mathrm{~h}$ (Fig. 5a and b). In turn, dislocation density decreased to $1.68 \times 10^{14} \mathrm{~m}^{-2}$ (Fig. 5c). Pronounced intensification of the $\gamma^{\prime \prime}$ phase precipitation was also noticed. Densely arranged precipitates were visible in TEM bright-field images (Fig. 5d) as well as the dark-field images recorded in the [002] spot of the $\gamma^{\prime \prime}$ phase (Fig. 5e and the corresponding SAED pattern in Fig. 5f). The density of the $\gamma^{\prime \prime}$ phase precipitates was higher in the cell walls areas than in the cell interiors. This observation can be correlated with the results of the EDS microanalysis of the initial stress-relief condition showing the high degree of $\mathrm{Nb}$ microsegregation to the cell walls, which creates the more favorable conditions for precipitation of the $\gamma^{\prime \prime}$ phase.
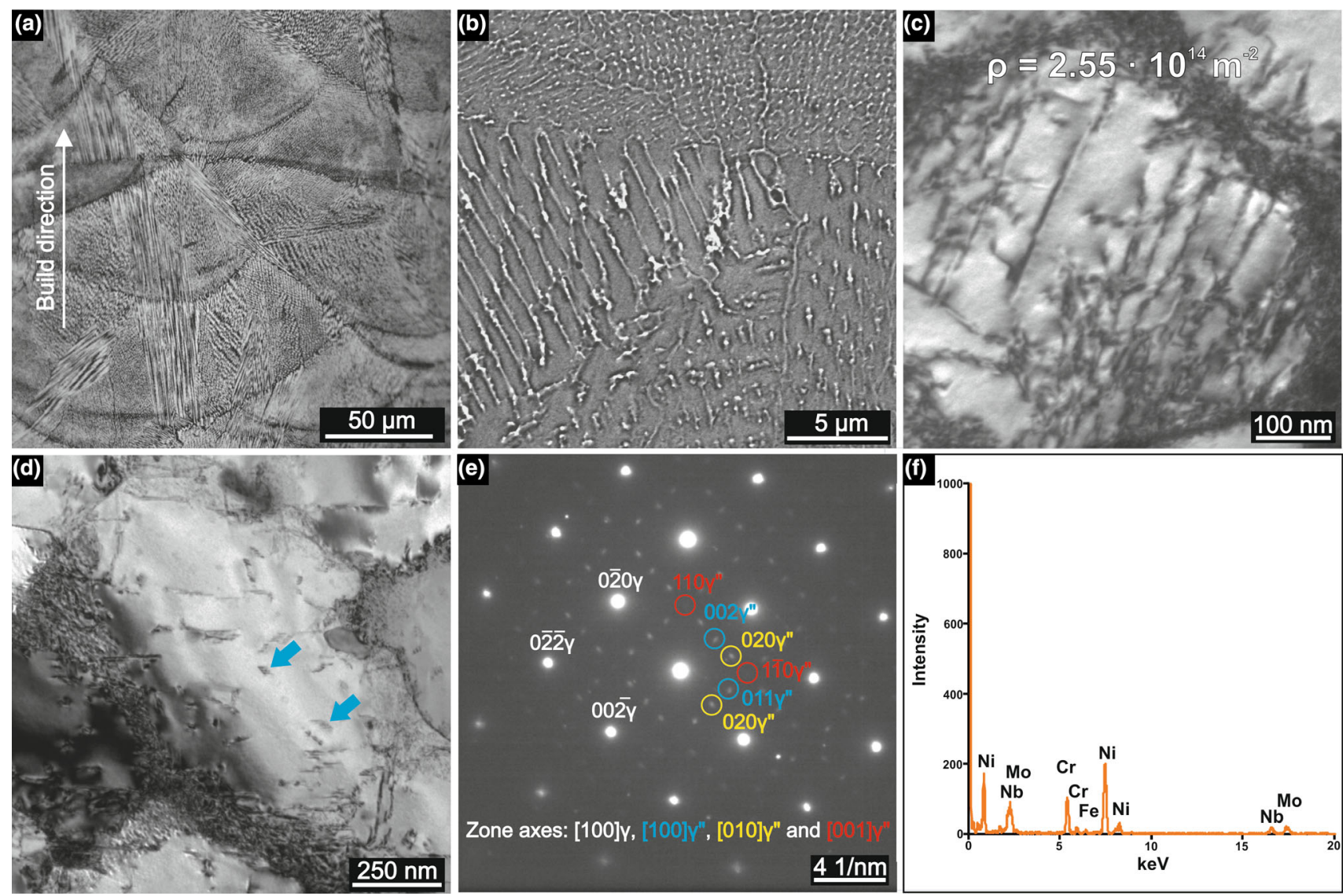

Fig. 4 Microstructure of the L-PBF Inconel 625 after stress-relief annealing at a temperature of $980{ }^{\circ} \mathrm{C}$ for $1 \mathrm{~h}$, followed by annealing at a temperature of $600{ }^{\circ} \mathrm{C}$ for $100 \mathrm{~h}$ : (a) LM image, (b) SEM image, as well as TEM images of (c) dislocations arrangements, (d) $\gamma^{\prime \prime}$ phase precipitates marked by arrows, (e) [100] zone axis SAED pattern with the $\gamma^{\prime \prime}$ phase diffraction spots of the [100] $\gamma^{\prime \prime},[010] \gamma^{\prime \prime}$ and [001] $\gamma^{\prime \prime}$ zone axes, (f) EDS spectrum from the area with the $\gamma^{\prime \prime}$ precipitate 

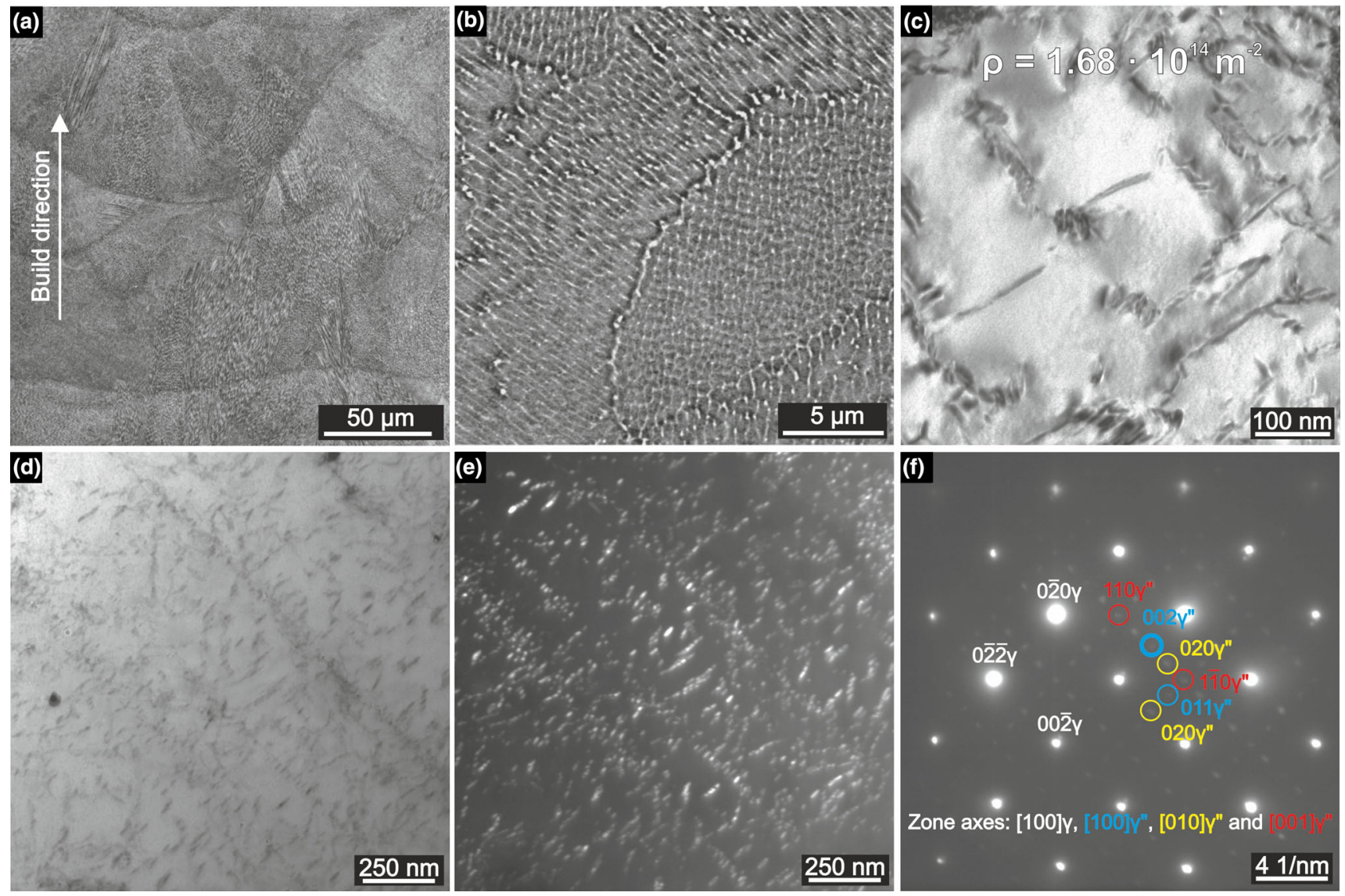

Fig. 5 Microstructure of the L-PBF Inconel 625 after stress-relief annealing at a temperature of $980{ }^{\circ} \mathrm{C}$ for $1 \mathrm{~h}$, followed by annealing at a temperature of $600{ }^{\circ} \mathrm{C}$ for $500 \mathrm{~h}$ : (a) LM image, (b) SEM image as well as TEM images of (c) of dislocations arrangements, (d, e) precipitates of the $\gamma^{\prime \prime}$ phase in bright-field and dark-field in the [002] $\gamma^{\prime \prime}$ spot, (f) [100] zone axis SAED pattern with the $\gamma^{\prime \prime}$ phase diffraction spots of the $[100] \gamma^{\prime \prime},[010] \gamma^{\prime \prime}$ and [001] $\gamma^{\prime \prime}$ zone axes; the [002] $\gamma^{\prime \prime}$ spot is highlighted in the bold circle

\section{Conclusions}

1. The fine cellular-dendritic microstructure of L-PBF Inconel 625 subjected to stress-relief annealing at a temperature of $980{ }^{\circ} \mathrm{C}$ for $1 \mathrm{~h}$ is characterized by high dislocation density.

2. Precipitates of the $\gamma^{\prime \prime}$ phase were found in L-PBF Inconel 625 annealed at a temperature of $600{ }^{\circ} \mathrm{C}$ for 5,100 and $500 \mathrm{~h}$. The plate-shaped nanoparticles of the $\gamma^{\prime \prime}$ phase precipitated on the $\{100\}$ planes of the $\gamma$ phase matrix.

3. With the prolongation of annealing duration at a temperature of $600{ }^{\circ} \mathrm{C}$, the gradual dissolution of intercellular areas and the decrease in the dislocation density was observed.

\section{Acknowledgments}

This research was funded by the National Science Centre, Poland, Grant No. 2017/27/B/ST8/02244.

\section{Open Access}

This article is licensed under a Creative Commons Attribution 4.0 International License, which permits use, sharing, adaptation, distribution and reproduction in any medium or format, as long as you give appropriate credit to the original author(s) and the source, provide a link to the Creative Commons licence, and indicate if changes were made. The images or other third party material in this article are included in the article's Creative Commons licence, unless indicated otherwise in a credit line to the material. If material is not included in the article's Creative Commons licence and your intended use is not permitted by statutory regulation or exceeds the permitted use, you will need to obtain permission directly from the copyright holder. To view a copy of this licence, visit http://creativecommons.org/licenses/by/4.0/.

\section{References}

1. S. Floreen, G.E. Fuchs, and W.J. Yang, Metallurgy of alloy 625, Superalloys 718, 625 and Various Derivatives, E.A. Loria, Ed., The Minerals, Metals and Materials Society, Warrendale, 1994, p 13-37

2. V. Shankar, K.B.S. Rao, and S.L. Mannan, Microstructure and Mechanical Properties of Inconel 625 Superalloy, J. Nucl. Mater., 2001, 228, p 222-232

3. L.E. Shoemaker, Alloys 625 and 725: Trends in Properties and Applications, Superalloys 718, 625 and Various Derivatives, E.A. Loria, Ed., The Minerals, Metals and Materials Society, Warrendale, 2005, p 409-418

4. J.A. Gonzalez, J. Mireles, S.W. Stafford, M.A. Perez, C.A. Terrazas, and R.B. Wicker, Characterization of Inconel 625 Fabricated Using Powder-Bed-Based Additive Manufacturing Technologies, J. Mater. Process. Technol., 2018, 264, p 200-210 
5. E.A. Lass, M.R. Stoudt, M.E. Williams, M.B. Katz, L.E. Levine, T.Q. Phan, T.H. Gnaeupel-Herold, and D.S. Ng, Formation of the Ni3Nb $\delta$ Phase in Stress-Relieved Inconel 625 Produced Via Laser Powder-Bed Fusion Additive Manufacturing, Metall. Mater. Trans., 2017, 48, p 5547-5558

6. A. Kreitcberg, V. Brailovskia, and S. Turenneb, Effect of Heat Treatment and Hot Isostatic Pressing on the Microstructure and Mechanical Properties of Inconel 625 Alloy Processed by Laser Powder Bed Fusion, Mater. Sci. Eng. A, 2017, 689, p 1-10

7. E.A. Lass, M.R. Stoudt, M.B. Katz, and M.E. Williams, Precipitation and Dissolution of $\delta$ and $\gamma^{\prime \prime}$ During Heat Treatment of a Laser PowderBed Fusion Produced Ni-Based Superalloy, Scr. Mater., 2018, 154, p 83-86

8. F. Zhang, L.E. Levine, A.J. Allen, C.E. Campbell, E.A. Lass, S. Cheruvathur, M.R. Stoudt, M.E. Williams, and Y. Idell, Homogenization Kinetics of a Nickel-Based Superalloy Produced by Powder Bed Fusion Laser Sintering, Scr. Mater., 2017, 131, p 98-102

9. G. Marchese, M. Lorusso, S. Parizia, E. Bassini, J.-W. Lee, F. Calignano, D. Manfredi, M. Terner, H.-U. Hong, D. Ugues, M. Lombardi, and S. Biamino, Influence of Heat Treatments on Microstructure Evolution and Mechanical Properties of Inconel 625 Processed by Laser Powder Bed Fusion, Mater. Sci. Eng. A, 2018, 729, p 64-75

10. K.N. Amato, J. Hernandez, L.E. Murr, E. Martinez, S.M. Gaytan, and P.W. Shindo, Comparison of Microstructures and Properties for a NiBase Superalloy (Alloy 625) Fabricated by Electron and Laser Beam Melting, J. Mater. Sci. Res., 2012, 1, p 1-41

11. T. Keller, G. Lindwall, S. Ghosh, L. Ma, B.M. Lane, F. Zhang, U.R. Kattner, E.A. Lass, J.C. Heigel, Y. Idell, M.E. Williams, A.J. Allen, J.E. Guyer, and L.E. Levine, Application of Finite Element, Phase-Field, and CALPHAD-Based Methods to Additive Manufacturing of NiBased Superalloy, Acta Mater, 2017, 139, p 244-253

12. F. Zhang, L.E. Levine, A.J. Allen, M.R. Stoudt, G. Lindwall, E.A. Lass, M.E. Williams, Y. Idell, and C.E. Campbell, Effect of Heat Treatment on the Microstructural Evolution of a Nickel-Based Superalloy Additive-Manufactured by Laser Powder Bed Fusion, Acta Mater, 2018, 152, p 200-214

13. C. Li, R. White, X.Y. Fang, M. Weaver, and Y.B. Gu, Microstructure Evolution Characteristics of Inconel 625 Alloy from Selective Laser Melting to Heat Treatment, Mater. Sci. Eng. A, 2017, 705, p 20-31

14. A. Kruse, A. Krupka, V. Schwarzkopf, C. Gamard, and T. Henningsen, Influence of Proteins on Hydrothermal Gasification and Liquefaction of Biomass. 2. Model Compounds, Ind. Eng. Chem. Res., 2007, 46, p 87-96

15. S. Saka and D. Kusdiana, Biodiesel Fuel from Rapeseed Oil as Prepared in Supercritical Methanol, Fuel, 2001, 80, p 225-231

16. K. Özdenkçi, C. De Blasio, G. Sarwar, K. Melin, J. Koskinen, and V. Alopaeus, Techo-Economic Feasibility of Supercritical Water Gasification of Black Liquor, Energy, 2019, 189, p 116284

17. R.K. Ham, The Determination of Dislocation Densities in Thin Films, Philos. Mag., 1961, 6, p 1183-1184

18. M. Calandri, S. Yin, B. Aldwell, F. Calignano, R. Lupoi, and D. Ugues, Texture and Microstructural Features at Different Length Scales in Inconel 718 Produced by Selective Laser Melting, Materials, 2019, 12, p $1-32$
19. J.P. Kruth, M. Badrossamay, E. Yasa, J. Deckers, L. Thijs, and J. Van Humbeeck, Part and Material Properties in Selective Laser Melting of Metals, in 16th International Symposium on Electromachining, Shangai, China, 19-23 April 2010, Red Hook, NY (2014), pp. 3-14

20. G.P. Dinda, A.K. Dasqupta, and J. Mazumder, Laser Aided Direct Metal Deposition of Inconel 625 Superalloy: Microstructural Evolution and Thermal Stability, Mater. Sci. Eng. A, 2009, 509, p 98-104

21. G.K. Dey, S. Albert, D. Srivastava, M. Sundararaman, and P. Mukhopadhyay, Microstructural Studies on Rapidly Solidified Inconel 625, Mater. Sci. Eng. A, 1989, 119, p 175-184

22. L.M. Suave, J. Cornier, P. Villechaise, A. Soula, Z. Hervier, D. Bertheau, and J. Laigo, Microstructural Evolution during Thermal Aging of Alloy 625: Impact of Temperature and Forming Process, Metall. Mater. Trans. A Phys. Metall. Mater. Sci., 2014, 45, p 29632982

23. F.J. Rizzo and J. Radavich, Microstructural Characterization of PM 625-Type Materials, Superalloys 718, 625 and Various Derivatives, E.A. Loria, Ed., The Minerals Metals and Materials Society, Warrendale, 1991, p 297-308

24. F. Cortial, J.M. Corrieu, and C. Vernot-Loier, Influence of Heat Treatments on Microstructure, Mechanical Properties, and Corrosion Resistance of Weld Alloy 625, Superalloys 718, 625 and Various Derivatives, E.A. Loria, Ed., The Minerals Metals and Materials Society, Warrendale, 1994, p 859-870

25. X. Xing, X. Di, and B. Wang, The Effect of Post-Weld Heat Treatment Temperature on the Microstructure of Inconel 625 Deposited Metal, J. Alloys Compd., 2014, 593, p 110-116

26. T.E. Abioye, D.G. McCartney, and A.T. Clare, Laser Cladding of Inconel 625 Wire for Corrosion Protection, J. Mater. Process. Technol., 2015, 217, p 232-240

27. P. Petrzak, K. Kowalski, and M. Blicharski, Analysis of Phase Transformations in Inconel 625 Alloy During Annealing, Acta Phys. Pol. A, 2016, 130, p 1041-1044

28. B. Dubiel and J. Sieniawski, Precipitates in Additively Manufactured Inconel 625 Superalloy, Materials, 2019, 12, p 1-11

29. M. Solecka, A. Kopia, A. Radziszewska, and B. Rutkowski, Microstructure, Microsegregation and Nanohardness of CMT Clad Layers of Ni-Base Alloy on 16Mo3 Steel, J. Alloys Compd., 2018, 751, p 86-95

30. M. Rozmus-Górnikowska, Ł. Cieniek, M. Blicharski, and J. Kusiński, Microstructure and Microsegregation of an Inconel 625 Weld Overlay Produced on Steel Pipes by the Cold Metall Tranfer Technique, Arch. Metall. Mater, 2014, 59, p 1081-1084

31. B. Dubiel, A. Kruk, E. Stępniowska, G. Cempura, D. Geiger, P. Formanek, J. Hernandez, P. Midgley, and A. Czyrska-Filemonowicz, TEM, HRTEM, electron holography and electron tomography studies of $\gamma^{\prime}$ and $\gamma^{\prime \prime}$ nanoparticles in Inconel 718 superalloy, J. Microsc., 2009, 236, p 149-157

Publisher's Note Springer Nature remains neutral with regard to jurisdictional claims in published maps and institutional affiliations. 